\title{
Incentive effects, monitoring mechanisms and the market for corporate control: an analysis of the factors affecting public to private transactions in the UK
}

\author{
Charlie Weir*, David Laing* and Mike Wright** \\ * The Aberdeen Business School \\ The Robert Gordon University \\ Garthdee Road \\ Aberdeen AB 10 7QE \\ ** Centre for Management Buy-out Research \\ Nottingham University Business School \\ University of Nottingham \\ Jubilee Campus \\ Wollaton Road \\ Nottingham NG8 1BB
}

Correspondence to

Professor Charlie Weir

Tel 01224263800

Email c.weir@rgu.ac.uk 
Incentive effects, monitoring mechanisms and the market for corporate control: an analysis of the factors affecting public to private transactions in the UK

\begin{abstract}
The paper investigates the factors that influence the decision to change the status of a publicly quoted company to that of a private company. We find that firms that go private are more likely to have higher CEO ownership and higher institutional ownership. In relation to their board structures, firms going private tend to have more duality but there is no statistical difference in the proportion of non-executive directors. They do not show signs of having excess free cash flows but there is some evidence of lower growth opportunities. We do not find that firms going private experience a greater threat of hostile acquisition. The results are therefore consistent with incentive and monitoring explanations of going private. Calculation of the probability of going private shows that incentive effects are stronger than the monitoring effects.
\end{abstract}

Keywords: public to private transactions: incentives: monitoring: market for corporate control 
Incentive effects, monitoring mechanisms and the market for corporate control: an analysis of the factors affecting public to private transactions in the UK

\section{INTRODUCTION}

The literature on take-overs tends to treat them as being either homogeneous, Palepu (1986) or it distinguishes between hostile and friendly take-overs, Morck et al (1988) and Shivdasani (1993). However, there is another type of take-over that has become more common in the US and UK in recent years, the public-toprivate transaction (PTP). This occurs when the equity of a publicly quoted company is purchased, the company goes private and is therefore no longer quoted on the stock market, Frankfurter and Gunay (1992). As Lehn and Poulsen (1989) note, a number of terms tend to be used interchangeably to describe the change in status from public-to-private company, although neither covers all PTPs. They identify the two most commonly used terms as "leveraged buyouts", because the PTP transactions are often heavily financed by debt, and "management buyouts" because the bidding party often includes the existing management team. This study analyses the governance characteristics of UK PTPs and compares them with the characteristics of companies that remained public.

The paper makes a number of contributions to the corporate governance literature. First, it investigates the extent of PTP activity in the UK. Throughout the 1990s, the UK experienced an increase in the incidence of friendly 
acquisitions to such an extent that hostile acquisitions only make up about $2 \%$ of the acquisition activity for quoted companies in the UK (Weir and Laing 2002). As shown in Table 2, public-to-private transactions constitute an increasing percentage of quoted take-overs in the UK, around a quarter in recent years. Further, during the years under study, 1998-2000, firms going private generated sales worth $£ 16.8$ billion and so it is important to address the factors that may explain this type of acquisition activity.

Second, the paper analyses the role played by internal monitoring mechanisms in the decision to go private. Board structure characteristics of 95 UK public-toprivate targets are compared with those of a matched sample of companies that remained publicly quoted. This is an important area of investigation given recent concerns about internal governance mechanisms of listed companies that reports such as Cadbury (1992) and Hampel (1998) in the UK, as well as others, such as the Sarbanes Oxley Act in the US, have sought to address. The impact of external monitoring by institutions is also investigated.

Third, we will also investigate how far incentive effects, in the form of share ownership, drive the decision to go private. We are unaware of any UK study that has investigated either of these two issues in relation to public to private changes. Fourth, we investigate the extent to which incentives and monitoring effects affect the probability of going private by presenting results on the probability of going private for different ownership structures. 
Fifth, the paper will evaluate the pressures imposed by the market for corporate control. A number of studies have identified this as significant factor, Lehn and Poulsen (1989), Singh (1990) and Halpern et al (1999). However, it is unclear how far they differentiate between hostile and non-hostile take-over interest as expressed in the take-over speculation reported in the financial press. The analysis is developed to show that refining the measurement of take-over speculation such that only hostile speculation is included, rather than any reported speculation, can have significant effects on the results.

These will allow us to test a number of agency-related hypotheses in relation to the going private decision. First, the extent to which going private is driven by incentive effects; second, the importance of monitoring effects; and third, how far PTP decisions are driven by the fear of hostile take-over and the presence of ineffective monitoring mechanisms.

Our results show that significant differences exist between the PTPs and the control sample. Firms going private have higher CEO shareholdings, higher institutional shareholdings and are more likely to have the same person acting as CEO and chairman. However, no evidence is found of a difference in nonexecutive director representation and neither do we find any evidence of excess free cash flow. We also find that firms going private are not subject to a greater threat of hostile take-over than firms that remain public. The results therefore 
provide support for the incentive and monitoring explanations for undertaking a PTP.

In a development of the analysis we tested a number of variables, including accounting performance. We find no evidence that firms going private had poorer accounting performance than firms remaining public. We also analysed tax advantages, which appear to influence the PTP decision in the US. However, we find that there is little similarity in the influences on the decision to go private in the US and UK. This may be explained by the tax advantages of financing firms through debt rather than equity applying more to the US than the UK, Dicker (1990).

\section{LITERATURE REVIEW}

Agency costs are incurred by shareholders, or principals, as a result of the separation of ownership and control, Jensen and Meckling (1976). Information asymmetry means that managers are able to pursue objectives such as corporate size rather than maximising shareholder wealth. A number of corporate governance mechanisms may be used to reduce the extent of the agency costs incurred by the principals. There are two main categories of governance mechanism, internal and external. Internal mechanisms can be split into monitoring and incentive related. Monitoring mechanisms refer to board structures, Fama (1980), Fama and Jensen, (1983), Cadbury (1992) and Greenbury (1995), external shareholdings, Shivdasani (1993), and debt, Jensen (1986b). The key incentive mechanism is internal shareholdings, Jensen and 
Meckling (1976). The main external corporate governance mechanism is the market for corporate control, Manne (1965) and Jensen (1986b), which acts as the mechanism of last resort if the internal mechanisms fail.

The issue then becomes one of explaining how PTPs reduce agency costs. ${ }^{1}$ The literature on public-to-private transactions can be split into a number of strands. The first deals with free cash flow. It argues that pre-PTP, agency costs are incurred because free cash flows are spent on projects that do not earn the required positive net present value, Jensen (1986b). These firms will exhibit low growth opportunities and large free cash flows. The free cash flows are used to achieve managerial objectives such as increased size and greater peer group standing rather than shareholder wealth maximisation. The ability to do this implies ineffective internal corporate governance mechanisms and management would only consider a move away from this situation if faced with an increased threat of hostile take-over. There is evidence that in the UK hostile take-overs result in a significant increase in the turnover of senior management postacquisition, Kennedy and Limmack (1996), Franks and Mayer (1996) and Dayha and Powell (1999). It is therefore in the interests of the incumbent management to take a company private and experience increased monitoring rather than risk losing their jobs. Job loss after a hostile take-over would damage their reputation and reduce their value on the executive labour market. 
US studies of the role of free cash flow in the decision to go private have produced mixed results. Lehn and Poulsen (1989) and Singh (1990) lend support to the free cash flow hypothesis by reporting that firms going private have greater free cash flow than firms remaining public. In addition, they found that PTPs exhibited lower sales growth, indicating poorer growth prospects, further supporting Jensen (1986b). However, Kieschnick (1998) reworked Lehn and Poulsen's sample using a weighted logistic regression and found free cash flow and sales growth to be insignificant. In addition, Opler and Titman (1993) also find no evidence that, individually, either free cash flow or Tobin's Q, influence the decision to go private. However, they do find that leveraged buyouts are more likely to exhibit the combined characteristics of low $\mathrm{Q}$ and high cash flow than firms remaining public. Further, Halpern et al (1999) also find no evidence to support the free cash flow hypothesis. Thus there is limited evidence that US PTPs exhibit excess free cash flow and poor growth prospects which suggests that going private is not being driven by the need to return free cash to the shareholders. The role of free cash flow in UK PTPs has not been investigated, something undertaken in this paper.

In relation to the second strand, there is evidence that shareholders of PTP firms make significant wealth gains. DeAngelo et al (1984) find significant positive returns on the announcement of a PTP and significant negative returns when it was announced that the PTP proposal had been withdrawn. Torabzadeh and Bertin (1987) find that significant abnormal returns accrue to the shareholders of 
PTP targets if financed by debt. Frankfurter and Gunay (1992) find that insider and outsider shareholders gain as a result of PTPs. In addition, Smith (1990) reported that there were significant improvements in post-buyout operating performance whereas failed MBO attempts did not produce any subsequent performance improvement. Thus there is strong evidence that PTPs generate gains to insider, and outsider, shareholders indicating that there are strong incentive effects in the decision to go private. This would also be consistent with Jensen and Meckling (1976) who argue that increased shareholdings help to align shareholder and director interests.

The third strand of previous studies deals with the market for corporate control, which is based on the premise that take-over bids are disciplinary and therefore hostile, Morck et al (1988). So if companies that went private had been the subject of take-over speculation whilst still publicly quoted, this implies ineffective internal governance mechanisms. The market for corporate control may therefore be regarded as a substitute for weak internal governance, Kini et al (1995). A number of studies, Lehn and Poulsen (1989), Singh (1990) and Halpern et al (1999), found that companies that went private were more likely to experience take-over speculation than firms that did not. However, Lehn and Poulsen (1989) combine competing bids with press take-over speculation and Halpern et al (1999) include any bids and rumours of interest. It therefore appears that these take-over speculation measures refer to general speculation about the possibility of the companies being taken-over. Some of the speculation may have been 
hostile and some not. Therefore we need a better understanding of the role of take-over speculation and rumour and its part in the decision to go private.

One aspect of the agency problem that has received little attention are the links between board composition, ownership structures and the PTP decision. ${ }^{2}$ In terms of ownership, a US study by Maupin et al (1984) found that the concentration of ownership amongst managers and directors was significantly higher in PTPs relative to firms that remain listed. In relation to of the internal corporate governance mechanisms of quoted companies, there has been an increasing international awareness of their role and importance. In the US the most recent is the Sarbanes Oxley Act 2002. In the UK, number of reports have specifically addressed the issue, Cadbury (1992), Greenbury (1995) and Hampel (1998), and have proposed that publicly quoted companies should adopt a Code of Best Practice, a proposal supported by the London Stock Exchange. ${ }^{3}$ Since June 1993, there has been a requirement that quoted companies include in their annual reports a statement explaining the extent to which they have adopted the internal governance mechanisms recommended in the Code.

The Code identifies a number of specific governance characteristics that are associated with good governance. The main board structure recommendations are that there should be a significant representation of non-executive (outside) directors and that the posts of CEO and chairman should be split. A significant representation is taken to be at least three non-executive directors. It is believed 
that this is the minimum number required for non-executive directors' views to carry weight at board meetings. The reason for separating the posts of CEO and chairman is, according to Cadbury, to prevent one person exercising too much power on board decisions.

The mechanisms identified in the Code would therefore be expected to mitigate the agency problems associated with weak internal governance. Firms that did not exhibit these structures are likely to be poor performers and be subject to hostile take-over threat. If the market for corporate control operates as hypothesised, ineffective corporate governance mechanisms should result in successful hostile bids being made, Fama (1980). For example, using US data, Morck et al (1988) and Shivdasani (1993) find governance differences between hostile targets and non-targets. In the UK, studies by Weir (1997) and O'Sullivan and Wong (1999) also found governance differences. The UK evidence showed that hostile targets were more likely to have fewer non-executive directors, more likely to have duality and have lower board shareholdings. These findings lend support for the governance structures recommended in the Code of Best Practice. Cadbury therefore provides a suitable framework against which to analyse the extent to which firms going private exhibit good or bad internal governance mechanisms.

The above discussion allows us to propose a number of hypotheses, based on the agency model, to explain the likelihood of a firm going private. The first 
hypothesis concerns the perceived threat from the market for corporate control. Consistent with this we would expect firms going private to have low managerial shareholdings, low external shareholdings, duality and low non-executive director representation. These characteristics would enable firms to generate large amounts of free cash flow and, as Jensen (1986a) argues, firms with substantial free cash flow and poor growth prospects are more likely to go private. The key motivation behind returning the free cash to the shareholders is to pre-empt a control threat such as a hostile take-over. In such a situation, the existence of excess free cash and poor growth prospects implies ineffective monitoring and incentive mechanisms and is consistent with the conditions present for the operation of the market for corporate control. In addition to the above, we would also expect that these companies would be subject to greater take-over threat than firms that remain public as other management teams move to bid for them.

Second, the financial incentive hypothesis argues that there are financial gains to be made by going private. In particular, taking a company private would yield substantial financial gains to the executive directors, particularly as they have been found to increase their shareholding post-PTP. For example, Frankfurter and Gunay (1992) report that insider shareholdings increase by an average of $58 \%$ post management buy-out. The higher the shareholding therefore, the greater the financial gain. We would therefore expect the probability of going private would be positively linked to executive director shareholdings. We would also expect the incentive effect to be present if the directors believed that the 
market was undervaluing the company. Thus the incentive hypothesis would also be consistent with a negative relationship between the $\mathrm{Q}$ ratio and the probability of going private.

Third, the effective monitoring hypothesis argues that the better the monitoring, the more likely that a public-to-private offer will be accepted, Bae et al (2000). An independent board that pursues shareholders' interests is indicative of effective internal monitoring. Thus boards with a greater proportion of non-executive directors will be more effective monitors. Similarly, boards that separate the posts of chief executive officer and chairman will be better able to influence decisions. Therefore, duality is less likely to be present in firms going private. More effective external monitoring will occur as institutional shareholdings increase and the free-rider problem is overcome. A summary of the expected relationships for each of the hypotheses is given in table 1.

\section{INSERT TABLE1}

\section{SAMPLE and DATA}

The sample consists of all public-to-private transactions that took place in the UK during 1998-2000 for which full data were available. PTPs are defined as taking place when a quoted stockmarket company is delisted as a result of a formal take-over by a financial institution such as a venture capitalist or LBO fund, by the executive directors or by another individual blockholder. We identified 116 PTPs during 1998-2000. After removing those involving financial firms and those with missing data, the final sample consists of 95 PTPs. The sample excludes 
financial services companies because they are subject to the external scrutiny of bodies like the Financial Services Authority. To be included, three years of prePTP financial data and complete governance information at the last year-end before the PTP took place is required. All data refer to the last year-end position before the PTP occurred.

A control sample was also constructed which consisted of a matched sample of 95 non-financial companies that had remained quoted on the London Stock Exchange during the period 1998-2000. The matching process was done by size and industry, (North 2001). Size was measured by sales and industry by the second level Financial Times Industrial Classification. The methodology used, matching by sample size, is known as choice-based sampling and classifies the population into groups based on outcomes, (Cosslet 1981). The outcome in this case being whether or not a company had gone private. Choice-based sampling may be appropriate where random sampling would give a small number of cases falling into a particular category, (Amemiya 1985). Relatively few firms, only around $2.05 \%$ of non-financial firms, changed their status from public to private so that, unless a randomly drawn sample was very large, random sampling would yield few companies making the change. This would create cost implications in relation to sample collection. Logistic regression is used in the analysis and Maddala (1991) argues that any bias present in choice based sampling will appear only in the constant of the regression. 
Information on PTP transactions was taken from four sources. First, Acquisitions Monthly, second, the Centre for Management Buyout Quarterly Review (CBMOR), third, the Financial Times and fourth, Extel Company News. Acquisitions Monthly is a corporate finance publication that provides data on major corporate deals such as take-overs, divestments, demergers and management buy-outs. The CMBOR is published by the Centre for Management Buyout Research at Nottingham University Business School and reports data on UK management buyouts. The CMBOR database effectively represents the population of management buyouts in the UK. Its data are primarily obtained from twice yearly surveys of corporate advisors, venture capital providers active in management buyouts. These surveys achieve an almost 100 per cent response rate. Financial data were taken from Extel Company Analysis, which provides accounting and stock market data taken directly from company annual reports and from the stockmarket. Corporate governance information was taken from the Price Waterhouse Corporate Register. This source contains information on board structures, director tenure, director biographies, director shareholdings and externally held shareholdings in excess of $3 \%$. Data on take-over speculation, threats and rumours were taken from FT Intelligence, an online database that provides full text newspaper reports.

The variables used in the analysis are defined as follows:

PTP - is a binary variable that takes the value 1 if a company had successfully undertaken a public to private transaction and 0 if it had remained public. PNX - is the percentage of non-executive directors on the board. 
PINDNX - is the percentage of independent directors on the board. Directors are classified as independent if they are non-executive directors that have not previously been employed previously either as an executive director of the company or had been employed as an advisor to the company.

DUALITY - is a binary variable that takes the value 1 if the same person holds the posts of CEO and chairman, and zero if the posts are held by different people.

CEOsh - is the percentage of ordinary shares held by the CEO, or where appropriate, the executive chairman.

XDsh - is the percentage of ordinary shares held by executive directors other than the CEO.

INSTITsh - is the total percentage shareholdings of institutions, where the shareholding is in excess of $3 \%$.

FCF - is a measure of free cash flow. It is defined as operating cash flow minus interest, tax and dividends deflated by sales and converted to a percentage. This measure is consistent with US studies such as Kieschnick (1998) and Halpern et al (1999),

SPECULATION - is a binary variable that takes the value 1 if a company had been the subject of take-over speculation in the financial press and zero if it had not. This covers the range of press speculation used in Lehn and Poulsen (1989) and Halpern et al (1999). The time period during which take-over speculation was measured was from one week before the announcement of the PTP to eighteen months before the PTP. 
$\mathrm{Q}$ - is the $\mathrm{Q}$ ratio and is defined as market capitalisation deflated by total assets.

It is a proxy for growth prospects, as perceived by the market.

The binary nature of the dependent variable means that logistic regression is appropriate. Logistic regression is based on the cumulative logistic probability function and takes the form:

$\mathrm{L}_{\mathrm{i}}=\ln \left(\frac{P_{i}}{1-P_{i}}\right)=\mathrm{Z}_{\mathrm{i}}$

where $L_{i}$ is the natural log of the odds that a firm will go private, given the explanatory variables and $Z_{i}$ is the regression equation specified below in the general model:

$Z_{i}=\beta_{0}+\beta_{1} P_{N X}+\beta_{2}$ DUAL $_{i}+\beta_{3}$ CEOsh $_{i}+\beta_{4}$ INSTITsh $_{i}+\beta_{5}$ FCF $_{i}+6_{7}$ SPECULATION $_{i}+\beta_{7} Q_{i}$

\section{RESULTS}

INSERT TABLE 2

Table 2 shows that, over the period 1991-1997, public-to-private transactions accounted for an average of $4.75 \%$ of total acquisition activity. During the period under study, 1998-2000, there was a sharp increase on the importance of publicto-private transactions in the UK with the average figure increasing to $23.7 \%$.

There has been no change in the definition of what constitutes a PTP. Evidence from detailed interviews with private equity financiers of buy-outs suggests that this step change arose through the coming together of a number of demand and supply factors, Wright et al (1999) and Burrows and Wright (2002). The period from 1995 saw substantial increases in the amount of equity funds raised to 
finance buy-outs. This in turn prompted increased competition between private equity firms for deals. In addition, corporate divestors, in an environment where corporate governance was gaining higher prominence, were also increasingly looking to auction divisions they no longer wanted to the highest bidder, whereas previously they may have given management preference. By bidding up the entry price, these auctions thus introduced a winner's curse-type problem as successful bidders had to undertake greater actions to generate the returns looked for by their limited partner investors. These factors encouraged private equity firms to seek fresh ways of investing funds in deals where there was likely to be less competition. In addition, PTPs are seen as relatively low risk compared to investment in start-ups or in high technology, especially for funds with generalist, later investment stage skills, Lockett, Murray and Wright (2002).

Consolidation amongst fund management firms has resulted in funds getting larger and consequently they have ignored smaller quoted companies because of the lack of liquidity in the sector. Many companies with a market capitalisation of less than $£ 20$ million are not researched by sell side investment analysts, Treasury (1998) and Golding (2001). The underperformance of the smaller quoted firm index and the low valuation of the smaller quoted company sector relative to the stockmarket have also contributed to the growth in PTPs. Institutional investors were increasingly finding that their holdings in smaller listed companies with few growth prospects were illiquid with market makers quoting large spreads on the shares and few analysts interested in this part of the 
market. This problem was exacerbated by the development of the dot-com boom as investors shifted their interest away from traditional sectors. Traditionally conglomerates like Hanson and BTR would have acquired poorly performing and/or undervalued small quoted companies but this option has declined as conglomerates themselves have fallen out of favour, particularly since the mid 1990s. As a result, institutional investors became more willing to sell to management buy-outs where previously, in the light of opportunistic management-led deals in the 1980s, they may have been more sceptical. At the same time, management in these firms, facing difficulties in raising funds to take advantage of perceived investment opportunities, became disillusioned with a stock market listing. Debt providers were also persuaded to become more willing to commit to lending to management buy-out cases of this kind thus helping private equity bidders to meet the certain funds requirements of the Take-over Code, even though the banks may not have obtained full security for several months [Sterling and Wright (1990)].

In addition, analysis of the press coverage reported in the sources used to gather information on PTPs identifies concerns about market valuation as the most commonly quoted reason for taking a company private, with $63 \%$ of firms giving it as a reason. This is consistent with the theoretical argument that institutional shareholders lack interest in these companies because of their size. ${ }^{4}$ Consequently, low market valuation could be a problem. These reports lend some initial support for the incentive and monitoring hypotheses. Low valuation 
makes it harder to raise equity on the stock market, something that will further adversely affect future prospects. The Report on Smaller Quoted Companies, Treasury (1998), was an attempt to address the problems faced by smaller quoted companies and their apparent low market valuation.

\section{INSERT TABLE 3}

Table 3 provides an overview of the descriptive statistics of both samples as well as the univariate analysis. The insignificant difference in the sales figures shows that the matching process was accurate. In terms of board structure, the average number of non-executive directors (NNX) of the public to private sample is 2.74 with the average number of independent directors (NINDX) being 2.33. Both are below the minimum of three non-executive directors recommended in the Code of Best Practice. The numbers of non-executive and independent non-executive, directors are significantly lower for PTPS. PTPs also have lower percentages of non-executive and independent non-executive directors, but the differences are not significant. The other board structure variable, duality, shows that PTPs have a significantly greater proportion of firms exhibiting this characteristic than do firms that remain public.

Table 3 also shows that PTPs have higher CEO and institutional shareholdings than companies remaining public. The difference for CEO shareholdings is significant at $1 \%$ and for institutional shareholdings at $10 \%$. However, there is no

difference between the shareholdings of the non-CEO executive directors suggesting that any incentive effects are being driven by CEO shareholdings 
rather than by other executive director shareholdings. PTPs also have significantly lower $\mathrm{Q}$ ratios. There is no evidence that the extent of free cash flow differs between the two types of firms. However, firms going private experienced significantly more take-over speculation than the non-acquired firms.

INSERT Table 4

The logistic multivariate results are presented in Table 4. Two models are presented because of the high correlation between the percentage of nonexecutive directors and the percentage of independent non-executive directors (the Pearson correlation is 0.79 ). In addition, CEO shareholdings is replaced by other executive director shareholdings in an attempt to evaluate the incentive effects of their shareholdings. Models 1 and 2 show that firms going private are more likely to have higher CEO shareholdings and higher institutional shareholdings. Their $\mathrm{Q}$ ratios however are not different. The non-executive director measures are not significantly different but duality is significantly more common in firms going private. Thus the impact of internal board structures on the probability of going private is unclear, particularly given that duality is one of the governance mechanisms that the Code of Best Practice identifies as being best avoided. We also find no evidence that free cash flow differences explain the probability of going private, a conclusion that is consistent with most US evidence.

Table 4 also shows that, for all four models, firms going private are more likely to experience take-over speculation than firms remaining public, (the role of the 
market for corporate control is examined further below). Models 3 and 4 provide limited evidence that there are incentive effects operating for the executive directors, other than the CEO. Model 4 also suggests that the boards of PTPs are less independent than firms that remain public. However, the insignificance on the $\mathrm{Q}$ ratio variable shows that the market does not regard them as having poorer growth opportunities. The multivariate results therefore offer support for the incentive and monitoring hypotheses with only the duality result providing support for the threat from the market for corporate control hypothesis. ${ }^{5}$

\section{INSERT Table 5}

As discussed earlier, a number of US studies have incorporated a 'footsteps', or take-over speculation variable, based on press reports of take-over interest, Lehn and Poulsen (1989), Kieschnick (1998) and Halpern et al (1999). Such interest has been taken to be hostile. As Table 5 shows, some $60 \%$ of firms that went private experienced bid speculation with only 14\% of non-PTPs, with the difference being statistically significant. This implies that, as shown in Table 4, the incumbent management is under strong pressure from the market for corporate control.

However, there are a number of potential problems with the use of reported takeover speculation. First, the source of the rumour is not usually specified and second, the reports merely make reference to the fact that take-over speculation has occurred. Press speculation may refer either to rumours that implicitly relate to a potential change of status from public to private or, alternatively, they may 
refer to the possibility that a rumour relates to a potential hostile bid. The speculation variable was therefore refined to clarify the extent to which PTPs faced a clear hostile threat. Two new measures were constructed. First, THREAT1, took a value of one if a company had been the subject of a bid that was reported as hostile, if there were multiple bidders for the company or there had been a proxy fight, and zero if not. This filters out the more general rumours and reports that relate to the possibility of a PTP happening and leaves only press speculation that identifies possible hostile intent or control contests by other bidders. It therefore gives a better measure of the pressure from the market for corporate control than, for example, Lehn and Poulsen (1989) who include all take-over rumours. As Table 5 shows, according to press reports, only 14\% of PTPs experienced this type of bid, something also experienced by $7.38 \%$ of firms that remained public. The difference is not statistically significant.

However, even removing competing bids does not provide a complete picture of the extent of hostile threat. For example, it is unclear if these competing bids occurred after the initial offer made by the incumbent management, that is, after news of a move to take the company private had been released to the market. In these circumstances, other firms expressing an interest does not strictly mean that any counter bid is hostile because the interest has been brought about after the target company had been put into play by its management. As a result, the expression of interest may be a consequence of the target's management putting the firm on the market rather than being a response to, for example, poor 
performance. Competing bids may therefore be part of an auction situation, Schwert (2000). ${ }^{6}$ We therefore further refined the speculation variable with THREAT2 including only those PTPs that were reported in the press as specifically having been the subject of a hostile bid. Table 5 shows that only $3.15 \%$ of PTPs, and $2.10 \%$ of firms remaining private experienced such interest, according to press coverage. This difference is also statistically insignificant.

Therefore, very few UK PTPs appear to have been undertaken in response to pressures from the market for corporate control because most of the speculation reported in by the press was not of a hostile nature. The inclusion of certain types of press speculation, therefore, has a significant impact on the extent to which the market for corporate control plays a part in the decision to go private. The results of earlier studies should therefore be treated with some caution.

INSERT Table 6

The impact of pressures from the market for corporate control was reassessed using these refined speculation definitions. The logistic regressions of Table 4 were rerun with the THREAT2 variable replacing the broader SPECULATION measure of take-over rumour. The results are presented in Table 6. There are a number of key changes that suggest that the way in which the market for corporate control is measured has important implications for the decision to go private.

First, in Table 6, we find that the $\mathrm{Q}$ ratio is now negative and significant rather than insignificant as reported in Table 4. Thus firms going private are perceived 
to have poorer growth opportunities than those remaining public. It therefore offers some support for the incentive hypothesis because of the perception that the market undervalues the companies. It is also consistent with the sentiments quoted in the press coverage of the decisions. The second change is that the threat of take-over becomes insignificant. Thus including only speculation that is consistent with the market for corporate control shows that firms going private did not experience greater pressure than did firms remaining private. Regressions were also run with THREAT1 but it was also insignificant and its inclusion did not affect the significance of any of the other variables. These results show that using a broad definition of press speculation can lead to an incorrect interpretation of the impact of the threat of take-over on the decision to go private.

The results therefore offer little support for the threat from the market for corporate control hypothesis because there is no evidence that the companies going private were actually under pressure from being acquired by hostile takeover. The findings are therefore more consistent with the incentive and monitoring hypotheses. In relation to the former, we find lower $\mathrm{Q}$ and higher CEO shareholdings in firms going private. Additional support for the incentive hypothesis is provided by the extent of the bid premium received by shareholders of firms going private. The premium received averaged $44.9 \%$ over the month prior to the announcement, a result consistent with DeAngelo et al (1984). ${ }^{7}$ This 
also suggests that there is a financial incentive for existing institutional shareholders to sell their shares and receive the premium.

In terms of the monitoring hypothesis, we find higher institutional shareholdings which suggests better external monitoring. This is consistent with interview evidence gathered by the CMBOR that, because of the costs of undertaking PTPs, venture capitalists attempt to reduce the risk of bid failure by selecting targets where they can persuade major shareholders to commit to the deal, (CMBOR 2001). Further, given that PTPs tend to be small, institutional shareholders may be more willing to accept offers for small, relatively slow growing firms because the transactions costs involved in tracking and overseeing these companies may outweigh the benefits, Treasury (1998). This is also in line with the views expressed in footnote 4 that those involved in taking companies private have the perception that the market undervalues them and makes it difficult to fund expansion because institutional investors are uninterested in them.

The duality coefficient is contrary to expectations. However, given that the median sales of PTPs is $£ 71.47$ million, duality may suggest more effective internal monitoring. This was recognised in the Hampel Report which, although concluding that the posts of CEO and chairman should be separated, stated that there should be a degree of flexibility in the consideration of the governance characteristics of smaller firms. It also stressed the importance of individual 
circumstances. Further, Cadbury and Hampel both argued that where the posts were combined, shareholders should be given some justification for it. It is therefore reasonable to assume that the governance arrangements of the firms in the sample had been agreed by the shareholders and that they had their support. Duality may therefore be an effective monitoring mechanism in small firms,

\section{ROBUSTNESS CHECKS}

Further analyses were undertaken in an attempt to gauge the extent to which the results are robust to different variable definition. First, a number of alternative performance measures were also tested. Accounting measures such as profit margins, the return on assets and the return on equity were included. All were found to be insignificant, which provides evidence that PTPs were not poor performers and had no reason to fear that a hostile take-over bid would be received. This further calls into question the use of take-over speculation as an explanatory variable without investigating the sentiments expressed in the press coverage.

Second, a number of US studies have looked at the impact of tax expenditures on the decision to go private. Kaplan (1989) found that there were significant tax savings associated with $\mathrm{MBO}$, derived from the increase in debt, and that this was an important source of wealth gains. Kieschnick (1998) shows that the ability to reduce tax is linked to the premiums paid to shareholders when going private. The potential tax benefits of PTPs are also found in Halpern et al (1999) 
who report that firms choosing to go private are more likely to have higher tax payments than companies remaining public. We measured tax expenditures as tax paid as a percentage of sales. The variable was insignificant suggesting that, contrary to US evidence, potential tax benefits are not a key determinant in the decision to go private in the UK. As noted earlier, differences in the tax regimes relating to the treatment of interest on debt between the two countries may help explain this finding, Dicker (1990).

Third, given the inconclusive nature of the impact of free cash flow in other studies, alternative measures of free cash flow were also tested. These were first, free cash flow net of internal capital expenditure deflated by sales and second, operating cash flow deflated by sales. Neither measure was found to be significant suggesting that excessive free cash flow is not a reason for going private, a finding consistent with Opler and Titman (1993) and Kieschnick (1998). Fourth, Lehn and Poulsen (1989) had found low sales growth increased the probability of going private. However, we found sales growth to be insignificant for a number of years pre-PTP, as did Kieschnick (1998). The results presented therefore appear to be robust.

\section{FURTHER ANALYSIS}

The above results show the importance of incentive and monitoring effects in the decision to go private. We analyse this decision further by investigating the probability of going private for different levels of CEO and institutional 
shareholdings. The population of non-financial quoted UK companies is 1634 for 1998, 1541 for 1999 and 1451 for 2000 (Price Waterhouse Corporate Register). This makes a total of 4626 over the three years. The number of PTPs over that period was 95 , which is $(95 / 4626)=2.05 \%$ of the population. Let $\mathrm{P}_{1}$ be the proportion of PTPs that were sampled $\left(100 \%\right.$ as defined) and $P_{2}$ be the proportion of PTP firms sampled (in relation to the total number of public quoted firms, 2.05\%). Then $\mathrm{P}_{1}=1$ and $\mathrm{P}_{2}=0.0205$ and the adjustment to the constant term is $\ln (1)-\ln (0.0205)=3.88$. The constant must therefore be reduced by 3.88 to overcome sampling bias, Maddala (1991). The probability of going private is then calculated by:

$\mathrm{P}_{\mathrm{I}}=\frac{1}{1+e^{-Z_{i}}}$

Inserting the mean values of the variables into the Model 1, Table 4 gives an overall probability of going private of $1.98 \%$. (The actual probability for nonfinancial firms over the period was 2.05\%).

\section{INSERT TABLE 7}

Table 7 shows the probability of being involved in going private for different levels of CEO shareholdings, with other variables measured at their means. It shows that for CEO shareholdings up to $30 \%$, the probability remains quite small, less than $5.8 \%$. At shareholdings of $70 \%$, the probability of going private, ceteris paribus, is $33.70 \%$. The table also shows that, as CEO ownership increases over $40 \%$, the probability of going private increases sharply with the largest incremental change in the probability (10.6 percentage points) being found in the range $60 \%$ to $70 \%$ share ownership. The figures are consistent with strong 
financial incentive effects at high CEO ownership. For comparison purposes, the probability of going private was also calculated for institutional shareholdings and it was found that they had a much smaller impact. For example, at $10 \%$ institutional share ownership, the probability of going private was $1.03 \%$ whereas at $70 \%$ institutional shareholdings, the probability of going private is only $6.81 \%$. These results suggest that the decision to go private is being driven by internal rather than external mechanisms and that incentive effects appear to be stronger than monitoring effects.

The above conclusion was examined further by looking at the interactions between monitoring and incentive effects as well as between internal and external monitoring. First, if the CEO had a large shareholding and was also the chairman, the combination would provide strong incentive and monitoring effects to take the company private, particularly if there was a perception that the market had a poor view of its growth prospects. Second, the relationship between internal and external monitoring was examined by looking at the interaction of institutional shareholdings and duality. A positive coefficient would imply that internal and external monitoring complemented each other in the decision to go public.

INSERT Table 8

The multivariate results with the interaction terms are reported in Table 8. The CEO shareholdings-duality interaction term is significant in models 8 and 10 . This suggests that combined, incentive and internal monitoring effects increase the 
probability of going private. This reinforces the earlier findings. However, as shown in models 7 and 9, the combination of internal and external monitoring has no effect on the decision to go private. Thus the combination of internal and external monitoring does not influence the PTP decision. These results also hold if the broader THREAT1 is used instead.

\section{CONCLUSIONS}

This paper has identified a number of governance mechanisms that differ between firms going private and those remaining publicly quoted. The results are consistent with incentive and monitoring hypotheses but not with the fear of the market for corporate control hypothesis. It may be that, in the context of increasing globalisation, these companies are too small to be attractive to a corporate buyer and therefore were under less pressure from the risk of takeover.

We find that firms going private are more likely to have higher CEO shareholdings, higher institutional shareholdings, more duality and lower $\mathrm{Q}$ ratios. However, we find that the presence of non-executive and independent directors was statistically insignificant as was the interaction between institutional shareholdings and duality. We also find that, adjusting press reports to exclude non-hostile rumours, there is no evidence that PTPs experience more pressure from the market for corporate control than firms remaining public. It is argued that duality may be regarded as a positive internal monitoring mechanism because 
PTP firms are small. This is supported by the lack of evidence of excess free cash flow, the fact that accounting performance is not worse and the lack of pressure from the market for corporate control. The results also show that different factors drive PTPs in the UK and US. The agency model has therefore been shown to offer insights into public to private activity in the UK and that there are different characteristics between countries.

The importance of CEO shareholdings is consistent with evidence that the most important factor in driving post-buy-out gains is management's equity stake, not high leverage [Denis (1994), Phan and Hill (1995) and Thompson et al (1992)]. This suggests that the financial performance of buy-out firms is not simply associated with free cash flow issues. Incentives for management may encourage them to seek out value maximising opportunities that they may not have previously done. However, entrepreneurial managers may also identify opportunities for innovation and growth that they were unable to exploit while the company remained listed. Their cognitive ability may enable them to identify opportunities on the basis of limited and private information but they may find it difficult to convince public markets, with monitoring by passive institutional investors and a short term focus, of the profitability of these opportunities [Wright et al (2000)]. By taking the company private with funding from specialist private equity firms who are able to understand the market, these opportunities may be realised. These transactions are typically less highly leveraged than traditional buy-outs in order to provide the firm with the financial flexibility to exploit growth 
opportunities. This suggests that an approach focused on reducing the agency costs of control may be more appropriate to cases where there is scope to enhance efficiency and less so to innovative cases that depend on managers' entrepreneurial mindset and an approach to active investor involvement comprising technical and market assistance and not just financial monitoring.

Public to private transactions can be viewed as part of a life-cycle approach to corporate governance and finance. Jensen (1989) argued that highly leveraged buyouts of listed companies represented the eclipse of the public corporation. In contrast, Rappaport (1990) took a shorter-term view, arguing that such buyouts would need to go public again to enable equity financiers to achieve their capital gains. The systematic evidence clearly shows heterogeneity of the longevity of buyouts. Between a fifth and a third return to public ownership within a three year period (depending on the country of study, whether equity backed or not and the size of the transactions) with a large proportion remaining as buyouts for periods well in excess of five years, Kaplan (1991) and Wright et al (1995). ${ }^{8}$

PTPs provide an opportunity to take a company private, restructure it and grow it so that it may be represented to the stock market, or acquisition market, at a later date. The trend to PTPs suggests that the public capital market does not function well for smaller firms and that private equity firms may have a role to play in funding these cases. The development of PTPs in sectors that do not fit the strict Jensen conditions for highly leveraged buy-outs, that is stable cash flows and low 
investment opportunities, suggests that private equity firms may have an important role as active investors in the governance and strategic direction of firms that the capital markets find difficult to fulfil. In terms of the development of the corporate governance debate, our findings add to the view that there may be alternative corporate governance mechanisms that are appropriate for different kinds of firms and at different points in the firm's life cycle. At an economy wide level, this suggests that the private equity market may be playing an important role in enhancing the performance of corporations that the public equity market cannot achieve.

The results open up a number of additional directions for further research. First, it would be interesting to analyse the relationship between the degree of undervaluation, the extent of the premiums paid at the time of the PTP, the extent of restructuring activities undertaken during the buyout period and the timing and forms of any eventual return to public ownership. Ultimately, such an analysis would shed light on claims that there is a market inefficiency that leads to firms being mistakenly undervalued or whether private equity firms taking firms private possess superior information and skills that enable them to effect significant capital gains.

Other areas of further research include first, the analysis of PTP activity in other advanced economies. There is evidence elsewhere in Europe of PTP activity, notably in France and Sweden, with some PTP transactions also appearing in 
Germany (CMBOR, 2002). The nascent Japanese buyout market is also experiencing a modest flow of PTPs (Wright and Kitamura, 2003). Second, public to private transactions make up a considerable proportion of firms that are takenover so it would be interesting to see how far there are differences between them and other target companies. For example, this might involve comparative analysis of performance and sectoral differences. This would allow us to assess the extent to which target firms were homogeneous in their characteristics or whether there are distinct subgroups within target firms. Third, some firms may be too small to be of interest to the financial press so that some hostile interest may not be identified from this source. Additional information on the nature of market for corporate control pressure would offer further insights into the process. Fourth, if problems in obtaining finance from the stock market influence the PTP decision, it may be fruitful to examine differences in share liquidity and trading volumes as indicators of the ability of different types of firm to obtain funds from this source.

\section{NOTES}

1. One way in which agency costs could be reduced would be from lower information costs as a result of having less disclosure costs and a reduced need to comply with various regulatory bodies. For example, the costs of a stockmarket listing are estimated to be up to $£ 1$ million per annum, even for smaller quoted companies. This figure was quoted in the Financial Times, $4^{\text {th }}$ March 1999 (Wain Homes to go private in $£ 88$ million buyout) and was given by the executive chairman of Wain Homes, who stated that the cost of stockmarket listing was a significant factor in their decision to go private.

2. With the exception of Bae et al (2000), no study has addressed the relationship between internal governance structures and the PTP decision. Their study investigated the LBO-LRC choice, where leveraged recapitalisation (LRC) refers to the decision to make a large debt-financed cash payout to existing 
shareholders. They report that LBOs have higher board shareholdings, have fewer independent directors and fewer outside blockholders than LRCs. They argue that these characteristics mean that LBO targets are less suitable for the stockmarket because they are less open to monitoring.

3. The most recent, Higgs (2003), looks specifically at the role of non-executive directors.

4. Comments from directors involved in the PTP process that were reported in the financial press support this view. For example, the chairman of Wain Homes, in the Financial Times, 4 March 1999, 'We feel unloved and unwanted....There has been a lack of investor appeal for small company shares over the last two or three years.' (Wain Homes to go private in $£ 88$ million buyout). The chairman of Goldsmiths, in the Guardian, 19 March 1999, states 'In the last two years there has been a significant change in attitude towards smaller companies. Investment managers are turning their backs on us..... good, solid engineering companies and retailers are being grossly undervalued.' (Goldsmiths turns its back on city investors).

5. Kieschnick (1998) argues that small samples result in bias in the standard errors and proposes the use of Manski and Lerman's (1977) weighted maximum likelihood estimator. This was applied to the data and the results were found to be identical to the results in Table 4 with one exception - the institutional shareholding variable became insignificant. This casts doubt on the monitoring hypothesis but has no effect on the incentive hypothesis and provides additional evidence that the market for corporate control hypothesis does not explain the decision to go private.

6. Research undertaken by CMBOR has found that auctions are becoming more common in PTPs, (CMBOR 2001).

7. The figure was calculated from data provided in Acquisitions Monthly and is the increase in the share price from 28 days before the PTP announcement to the day of the announcement.

8. The CMBOR database shows that PTPs generally have a lower exit rate than all buyouts of a comparable size. For example, over the period 1985-1999, and using deals with a transaction value in excess of $£ 10$ million, which covers most PTPs, the figures show that $15.5 \%$ of these PTPs had exited by a trade sale, $8.7 \%$ by IPO, $5.8 \%$ by secondary buyout and $10.7 \%$ had failed. The comparable figures for all deals in this size range were $29.8 \%, 12.4 \%, 9.2 \%$ and $9.4 \%$ respectively. Over this 15 year period, the exit rate of PTPs with an initial deal value of $£ 10$ million by vintage year, that is when the deal was completed, has exceeded that for all buyouts in only five of the years. It is worth noting that the percentage of deals in this value range exited by vintage year in the periods of most PTP activity (1988-1990 and 1997-1999) is greater for all deals than for PTPs. Thus for $1988-1990$, the exit rate for PTPs is $50 \%, 69.2 \%$ and $50 \%$ : for all deals the figures are $81.5 \%, 86.6 \%$ and $80.6 \%$. For $1997-1999$, the figures are: PTPs $-28.6 \%, 33.3 \%$ and $21.1 \%$ and for all deals $50.6 \%, 42.3 \%$ and $27.3 \%$. This would seem to raise questions about the ex post ability of financial investors to create value from PTPs. 


\section{REFERENCES}

Amemiya, T. (1985) Advanced Econometrics, Blackwell, Oxford

Bae, S.C., Hendershott, R.J. and Jo, H. (2000) "Choosing an organisational form: leveraged buyouts versus leveraged recapitalisations". Working Paper Bowling Green State University

Burrows, A. and Wright, M. (2002) "Public to private buy-outs in UK and continental Europe", Management Buyouts, Winter

Cadbury Committee (1992) Report of the Committee on the Financial Aspects of Corporate Governance, Gee, London.

CMBOR (2001 Management Buy-outs: Quarterly Review from CMBOR. University of Nottingham: Centre for Management Buy-out Research

CMBOR (2002) European Buyout Review University of Nottingham: Centre for Management Buy-out Research

Cosslet, S. (1981) 'Efficient estimation of discrete choice models' in Manski, C. and McFadden, D. (eds) Structural Analysis of Discrete Data with Econometric Applications, MIT Press

Dahya, J. and Powell, R. (1999) Top Management Changes Following Hostile and Friendly Take-overs, ACCA Research Report, 61. London.

DeAngelo, H., DeAngelo, L. and Rice, E. (1984) "Going private: minority freezeouts and stockholders' wealth", Journal of Law and Economics, 27, 367402. 
Denis, D. (1994) "Organisational form and the consequences of highly leveraged transactions: Kroger's recapitalisation and Safeway's LBO" Journal of Financial Economics, 36, 193-224.

Dicker, A. (1990) "Tax Issues", In De Caires, B. (ed), Corporate Restructuring, (London, 1990).

Fama, E.F. (1980) "Agency problems and the theory of the firm", Journal of Political Economy, 88, 134-145.

Fama, E and Jensen, M. (1983) 'Separation of ownership and control', Journal of Law and Economics, 40, 301-349

Frankfurter, G.M. and Gunay, E. (1992) "Management buy-outs: the sources and sharing of wealth between insiders and outside shareholders", Quarterly Review of Economics and Finance, 32, 82-95.

Franks, J. and Mayer, C. (1996) "Hostile take-overs and the correction of managerial failure", Journal of Financial Economics, 40, 163-181.

Golding, T. (2002) The City: Inside the Great Expectations Machine: Myth and Reality in Institutional Investment and the Stock Market, FT Prentice Hall, London.

Greenbury, R. (1995) Directors' Remuneration: Report of the Study group Chaired by Sir Richard Greenbury, Gee, London.

Halpern, P., Kieschnick, R. and Rotenberg, W. (1999) "On the heterogeneity of leveraged going private transactions", The Review of Financial Studies, 12, 281309. 
Halpern, P., Kieschnick, R. and Rotenberg, W. (2000) "Why firms engaged in levered recapitalisation rather than levered buyout", Working Paper University of Texas at Dallas.

Hampel, R. (1998) Committee on Corporate Governance: Final Report, Gee, London.

Higgs, D. (2003) Review of the Role and Effectiveness of Non-Executive Directors, Department of Trade and Industry, London

Jensen, M. (1986a) "Agency costs of free cash flow, corporate finance and takeovers", American Economic Review, 76, 323-339.

Jensen, M. (1986b) "The take-over controversy: analysis and evidence", Midland Corporate Finance Journal, 4, 323-329.

Jensen M.J. (1989) "The eclipse of the public corporation", Harvard Business Review, Sept/Oct, 61-75.

Jensen, M.J. and Meckling, W.H. (1976) "Theory of the firm: managerial behaviour, agency costs and ownership structure", Journal of Financial Economics, 13, 305-360.

Kaplan, S. (1989) "Management buyouts: evidence on taxes as a source of value", Journal of Finance, 64, 611-632.

Kaplan, S. (1991) "The staying power of leveraged buy-outs", Journal of Financial Economics, 29, 287-313.

Kennedy, V. and Limmack, R. (1996) "Take-over activity, CEO turnover, and the market for corporate control", Journal of Business Finance and Accounting, 23, 267-293. 
Kieschnick, R. (1998) "Free cash flow and stockholder gains in going private transaction revisited", Journal of Business Finance and Accounting, 25, 187-202. Kini, O., Kracaw, W. and Mian, S. (1995) 'Corporate takeovers, firm performance and board composition', Journal of Corporate Finance, 1, 383-412.

Lehn, K. and Poulsen, A. (1989) "Free cash flow and stockholder gains in going private transactions", The Journal of Finance, XLIV, 771-787

Lockett, A., Murray, G. and Wright, M. (2002) "Do venture capitalists still have a bias against technology-based firms? Research Policy, 31, 1009-1030.

Maddala, G.S. (1991) 'A perspective in the use of limited dependent and qualitative variables models in accounting research', The Accounting Review, 66, 788-807.

Manne, H.G. (1965) 'Mergers and the market for corporate control', Journal of Political Economy, 73, 110-120.

Manski, C.F. and S.R. Lerman (1977) "The estimation of choice probabilities from choice based samples", Econometrica, 45, 1977-1988.

Maupin, R.J., Bidwell and Ortegren (1984) "An Empirical Investigation of the Characteristics of Publicly Quoted Companies Which Change to closely held ownership through management buy-outs", Journal of Business Finance and Accounting, 11, 345-59.

Morck, R., Shleifer, A. and Vishny, R.W. (1988) "Characteristics of targets of hostile and friendly take-overs" in Corporate Take-overs: Causes and Consequences, Auerbach, A.J (ed), University of Chicago Press. IL. 
North, D.S. (2001) 'The role of managerial incentives in corporate acquisitions: evidence from the 1990s'. Journal of Corporate Finance, vol 7, pp 125-149.

Opler, T. and Titman, S. (1993) "The determinants of leveraged buyout activity: free cash flow vs. financial distress costs". The Journal if Finance ,XLVIII, 19851999.

O'Sullivan, N. and Wong, P. (1999) "Board composition, ownership structure and hostile take-overs: some UK evidence", Accounting and Business Research, 29, 139-155.

Palepu, K.G. (1986) Predicting take-over targets: a methodological and empirical analysis" Journal of Accounting and Economics, 8, 3-35.

Phan, P. and Hill, C.W.L. (1995) "Organisational restructuring and economic performance in leveraged buyouts: an ex post study", Academy of Management Journal, 38, 704-739.

Rappaport, A. (1990) "The staying power of the public corporation", Harvard Business Review, Jan/Feb

Schwert, G.W. (2000) 'Hostility in take-overs: in the eyes of the beholders', Journal of Finance, 55, 2599-2640.

Shivdasani, A. (1993) "Board composition, ownership structure and hostile takeovers", Journal of Accounting and Economics, 16, 167-198.

Singh, H. (1990) "Management Buyouts and Shareholder Value", Strategic Management Journal, 111-29.

Smith, A. (1990) "Capital ownership structure and performance: the case of management buyouts", Journal of Financial Economics, 13, 143-165. 
Sterling, M. and Wright, M. (1990) Management Buyouts and the Law, Oxford, Blackwell Scientific.

Torabzadeh, K.M and Bertin, W.J. (1987), "Leveraged buyouts and shareholder returns", The Journal of Financial Research, 10, 313-319.

Treasury, The (1998) Smaller Quoted Companies: A Report to the Paymaster General, London

Weir, C.M. (1997) "Corporate governance, performance and take-overs: an empirical analysis of UK mergers", Applied Economics, 29, 1465-1475.

Weir, C.M. and Laing, D. (2002) 'Governance characteristics and non-hostile take-overs in the UK: an empirical analysis. Paper presented to the Financial Management Association Conference, San Antonio.

Wright, M. Hoskisson, R., Busenitz, L. and Dial, J. (2000) "Entrepreneurial growth through privatisation: the upside of management buy-outs", Academy of Management Review, 25, 591-601.

Wright, M., Robbie, K., and Burrows, A. (1998) "UK public to private buy-outs", Management Buyouts, Winter, 19-40.

Wright, M., Thompson, S. and Robbie, K. (1992) "Management led leveraged buy-outs: a European perspective", Journal of Business Venturing, 7, 47-72.

Wright, M., Thompson, S., Robbie, K and Wong, P. (1995) "Management buyouts in the short and long term", Journal of Business Finance and Accounting, 22, 461-482.

Wright, M and Kitamura, M. (2003) "Management Buyouts in Japan", Journal of Private Equity, forthcoming 
Table 1 Summary of hypotheses and expected signs

\begin{tabular}{|c|c|c|c|}
\hline & $\begin{array}{c}\text { Fear of the } \\
\text { Market for } \\
\text { Corporate } \\
\text { Control }\end{array}$ & $\begin{array}{l}\text { Financial } \\
\text { incentive }\end{array}$ & $\begin{array}{l}\text { Effective } \\
\text { monitoring }\end{array}$ \\
\hline \multicolumn{4}{|l|}{ (i) Shareholdings } \\
\hline - CEO & - & + & na \\
\hline $\begin{array}{l}\text { - institutional } \\
\text { (ii) Board }\end{array}$ & - & na & + \\
\hline Independence & & & \\
\hline $\begin{array}{l}\text { - non executive } \\
\text { directors }\end{array}$ & - & na & + \\
\hline - duality & + & na & - \\
\hline (iii) Others & & & \\
\hline - Free cash flow & + & na & na \\
\hline - Q ratio & - & - & na \\
\hline $\begin{array}{l}\text { - Take-over } \\
\text { interest }\end{array}$ & + & na & na \\
\hline
\end{tabular}

+ high values will increase the probability of going private

- high values will decrease the probability of going private

na means that the variable will have no effect on the probability of going private 
Table 2 Total number of public to private transactions as percentage of total merger activity

\begin{tabular}{|c|c|c|c|c|}
\hline \multicolumn{2}{|l|}{ Year } & Number of PTPs & Number of & PTPs a $\%$ of \\
\hline 1991 & & 6 & 91 & 6.6 \\
\hline 1992 & & 4 & 59 & 6.7 \\
\hline 1993 & & 1 & 58 & 1.7 \\
\hline 1994 & & 3 & 63 & 4.8 \\
\hline 1995 & & 3 & 87 & 3.4 \\
\hline 1996 & & 4 & 87 & 4.6 \\
\hline 1997 & & 7 & 127 & 5.5 \\
\hline 1998 & & 27 & 162 & 16.7 \\
\hline 1999 & & 46 & 192 & 24.0 \\
\hline 2000 & & 43 & 142 & 30.3 \\
\hline $\begin{array}{l}\text { Average } \\
2000\end{array}$ & 1998- & & & 23.7 \\
\hline
\end{tabular}

Source: Centre for Management Buy-out Research 
Table 3 Univariate analysis of board structure, ownership and performance characteristics of public to private and remaining public firms

\begin{tabular}{|c|c|c|c|c|c|c|c|c|c|}
\hline & \multicolumn{4}{|c|}{ Public to private sample } & \multicolumn{4}{|c|}{ Matched non-acquired sample } & \multirow[b]{2}{*}{ T test } \\
\hline & Min & Max & Mean & Median & Min & Max & Mean & Median & \\
\hline \multicolumn{10}{|l|}{ (i) Board } \\
\hline NNX & 0 & 11 & 2.74 & 3.00 & 0 & 15 & 3.18 & 3.00 & $1.93^{\star}$ \\
\hline NINDX & 0 & 11 & 2.33 & 3.00 & 0 & 14 & 2.74 & 2.00 & $1.71^{*}$ \\
\hline PNX (\%) & 0 & 75.00 & 43.10 & 42.85 & 0 & 88.24 & 44.74 & 42.85 & 0.76 \\
\hline PINDNX (\%) & 0 & 73.33 & 36.30 & 37.50 & 0 & 82.35 & 38.06 & 33.33 & 0.68 \\
\hline Duality & 0 & 1 & 0.29 & 0 & 0 & 1 & 0.17 & 0 & $2.11^{\star *}$ \\
\hline \multicolumn{10}{|l|}{ (ii) Shares } \\
\hline $\begin{array}{l}\text { CEOsh } \\
(\%)\end{array}$ & 0 & 72.50 & 11.54 & 3.51 & 0 & 73.53 & 5.97 & 1.30 & $3.16^{\star \star \star}$ \\
\hline XDsh (\%) & 0 & 66.64 & 7.00 & 1.73 & 0 & 66.69 & 5.79 & 0.97 & 0.76 \\
\hline $\begin{array}{l}\text { INSTITsh (\%) } \\
\text { (iii) Free cash }\end{array}$ & 0 & 74.80 & 32.98 & 33.60 & 0 & 88.58 & 27.86 & 26.27 & $1.96^{*}$ \\
\hline FCF & -38.82 & 41.28 & 4.33 & -3.42 & -27.12 & 28.09 & 4.56 & -0.81 & 0.19 \\
\hline $\mathrm{Q}$ & 0.04 & 3.38 & 0.79 & 0.62 & 0.17 & 11.32 & 1.08 & 0.85 & $3.52^{\star}$ \\
\hline \multicolumn{10}{|l|}{ (iv) Others } \\
\hline Speculation & 0 & 1 & 0.60 & 1 & 0 & 1 & 0.14 & 0 & $43.79 * \star \star$ \\
\hline Sales $(£ m)$ & 0.80 & 2578.57 & 177.30 & 71.47 & 2.27 & 2456.36 & 179.27 & 104.60 & 0.18 \\
\hline $\begin{array}{l}\text { Market } \\
\text { capitalisation } \\
(£ \mathrm{~m})\end{array}$ & 1.08 & 1112.00 & 29.95 & 80.31 & 2.41 & 2047.36 & 33.79 & 126.36 & $1.98^{*}$ \\
\hline
\end{tabular}

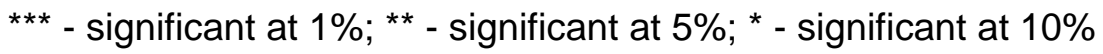

Paired t test used except for DUALITY and SPECULATION which used the chi square test

NNX is the number of non-executive directors. NINDNX is the number of independent nonexecutive directors. Directors are classified as independent if they are non-executive directors who have not previously been previously employed either as an executive director of the company or had been employed as an advisor to the company PNX is the percentage of nonexecutive directors on the board. PINDNX is the percentage of independent directors on the board. DUALITY is a binary variable that takes the value 1 if the same person holds the posts of CEO and chairman, and zero if the posts are held by different people. CEOsh is the percentage of ordinary shares held by the CEO, or where appropriate, the executive chairman. XDsh - is the percentage of ordinary shares held by executive directors other than the CEO. INSTITsh is the total percentage shareholdings of institutions, where the shareholding is in excess of $3 \%$. FCF is a measure of free cash flow. It is defined as operating cash flow minus interest, tax and dividends deflated by sales and converted to a percentage. SPECULATION is a binary variable that takes 
the value 1 if a company had been the subject of take-over speculation in the financial press and zero if it had not. $\mathrm{Q}$ is the $\mathrm{Q}$ ratio and is defined as market capitalisation deflated by total assets. MARKET CAPITALISATION is the market value of the company 
Table 4 Logistic regression results of the board, ownership and growth opportunity characteristics of public to private firms and firms remaining public.

\begin{tabular}{|c|c|c|c|c|}
\hline & Model 1 & Model 2 & Model 3 & Model 4 \\
\hline Q & $\begin{array}{l}-0.4289 \\
(1.57)\end{array}$ & $\begin{array}{l}-0.4414 \\
(1.61)\end{array}$ & $\begin{array}{l}-0.2796 \\
(1.15)\end{array}$ & $\begin{array}{l}-0.2890 \\
(1.17)\end{array}$ \\
\hline PNX & $\begin{array}{l}0.0008 \\
(0.06)\end{array}$ & & $\begin{array}{l}-0.0140 \\
(1.18)\end{array}$ & \\
\hline PINDNX & & $\begin{array}{l}-0.0058 \\
(0.53)\end{array}$ & & $\begin{array}{l}-0.0173 \\
(1.65)^{\star}\end{array}$ \\
\hline Duality & $\begin{array}{l}1.1059 \\
(2.57)^{\star \star}\end{array}$ & $\begin{array}{l}1.0882 \\
(2.51)^{\star \star}\end{array}$ & $\begin{array}{l}0.8769 \\
(2.12)^{\star \star}\end{array}$ & $\begin{array}{l}0.8788 \\
(2.14)^{\star \star}\end{array}$ \\
\hline CEOsh & $\begin{array}{l}0.0514 \\
(3.34)^{\star \star \star}\end{array}$ & $\begin{array}{l}0.0488 \\
(3.24)^{\star \star \star}\end{array}$ & & \\
\hline XDsh & & & $\begin{array}{l}0.0267 \\
(1.62)\end{array}$ & $\begin{array}{l}0.0274 \\
(1.65)^{*}\end{array}$ \\
\hline INSTITsh & $\begin{array}{l}0.0236 \\
(2.27)^{\star \star}\end{array}$ & $\begin{array}{l}0.0241 \\
(2.30)^{\star \star}\end{array}$ & $\begin{array}{l}0.0139 \\
(1.46)\end{array}$ & $\begin{array}{l}0.0155 \\
(1.60)\end{array}$ \\
\hline FCF & $\begin{array}{l}-0.0233 \\
(1.12)\end{array}$ & $\begin{array}{l}-0.0236 \\
(1.14)\end{array}$ & $\begin{array}{l}-0.0069 \\
(0.33)\end{array}$ & $\begin{array}{l}-0.0064 \\
(0.30)\end{array}$ \\
\hline Speculation & $\begin{array}{l}2.2762 \\
(5.73)^{\star \star \star}\end{array}$ & $\begin{array}{l}2.2985 \\
(5.74)^{\star \star \star}\end{array}$ & $\begin{array}{l}2.3126 \\
(5.99)^{\star \star \star}\end{array}$ & $\begin{array}{l}2.3700 \\
(6.04)^{\star \star \star}\end{array}$ \\
\hline Constant & $\begin{array}{l}-1.7646 \\
(2.14)^{\star \star}\end{array}$ & $\begin{array}{l}-1.4906 \\
(2.25)^{\star \star}\end{array}$ & $\begin{array}{l}-0.7120 \\
(1.02)\end{array}$ & $\begin{array}{l}-0.7506 \\
(1.27)\end{array}$ \\
\hline$\chi^{2}$ & $69.48^{\star \star \star}$ & $69.77^{\star \star \star}$ & $58.86^{\star \star \star *}$ & $60.29 * \star \star$ \\
\hline
\end{tabular}

$\mathrm{t}$ values in parentheses

*** - significant at $1 \%$; ** - significant at $5 \%$ : * - significant at $10 \%$

$\chi^{2}$ tests the null hypothesis that all the coefficients are zero.

PNX is the percentage of non-executive directors on the board. PINDNX is the percentage of independent directors on the board. Directors are classified as independent if they are nonexecutive directors who have not previously been previously employed either as an executive director of the company or had been employed as an advisor to the company. DUALITY is a binary variable that takes the value 1 if the same person holds the posts of CEO and chairman, and zero if the posts are held by different people. CEOsh is the percentage of ordinary shares held by the CEO, or where appropriate, the executive chairman. XDsh - is the percentage of ordinary shares held by executive directors other than the CEO. INSTITsh is the total percentage shareholdings of institutions, where the shareholding is in excess of 3\%. FCF is a measure of free cash flow. It is defined as operating cash flow minus interest, tax and dividends deflated by sales and converted to a percentage. SPECULATION is a binary variable that takes the value 1 if a company had been the subject of take-over speculation in the financial press and zero if it had not. $\mathrm{Q}$ is the $\mathrm{Q}$ ratio and is defined as market capitalisation deflated by total assets. 
Table 5 Measures of the threat from the market for corporate control

PTP (\%) $\quad$ Match (\%) $\quad$ Chi square

Speculation

60.00

14.00

$43.79^{\star \star \star}$

Threat 1

14.70

7.38

2.62

Threat 2

3.15

2.10

0.65

$\star \star \star$ - significant at $1 \%$

SPECULATION is a binary variable that takes the value one if the company had been the subject of take-over speculation in the financial press and zero if it had not. THREAT 1 is a binary variable that takes the value one if a company had been the subject of a bid that was reported in the financial press as hostile, had received multiple bidders or had been in a proxy fight and zero in not. THREAT2 is a binary variable that takes the value one if a company had been the subject of a hostile bid according to reports in the financial press and zero if it had not. 
Table 6 Logistic regression results of the board, ownership and growth opportunity characteristics of public to private firms and firms remaining public with only hostile interest included as a variable

\begin{tabular}{lll}
\hline & Model 5 & Model 6 \\
Q & -0.5020 & -1.1146 \\
PNX & $(2.00)^{\star \star}$ & $(1.87)^{\star}$ \\
PINDNX & 0.0038 & \\
& $(0.33)$ & 0.0007 \\
Duality & & $(0.07)$ \\
& & 0.8731 \\
CEOsh & 0.8959 & $(2.25)^{\star \star}$ \\
INSTITsh & $(2.28)^{\star \star}$ & 0.0514 \\
& 0.0526 & $(3.54)^{\star \star \star}$ \\
FCF & $(3.57)^{\star \star \star}$ & 0.0324 \\
& 0.0324 & $(3.40)^{\star \star \star}$ \\
Threat2 & $(3.41)^{\star \star \star}$ & -0.0234 \\
Constant & -0.0231 & $(1.24)$ \\
& $(1.23)$ & 0.3264 \\
$\lambda^{2}$ & 0.3267 & $(0.32)$ \\
\hline
\end{tabular}

$\mathrm{t}$ values in parentheses

*** - significant at 1\%; ** - significant at 5\%; * - significant at $10 \%$

$\chi^{2}$ tests the null hypothesis that all the coefficients are zero.

PNX is the percentage of non-executive directors on the board. PINDNX is the percentage of independent directors on the board. Directors are classified as independent if they are nonexecutive directors who have not previously been previously employed either as an executive director of the company or had been employed as an advisor to the company. DUALITY is a binary variable that takes the value 1 if the same person holds the posts of CEO and chairman, and zero if the posts are held by different people. CEOsh is the percentage of ordinary shares held by the CEO, or where appropriate, the executive chairman. INSTITsh is the total percentage shareholdings of institutions, where the shareholding is in excess of 3\%. FCF is a measure of free cash flow. It is defined as operating cash flow minus interest, tax and dividends deflated by sales and converted to a percentage. THREAT2 is a binary variable that takes the value 1 if a company had been the subject of hostile take-over speculation in the financial press and zero if it had not. $\mathrm{Q}$ is the $\mathrm{Q}$ ratio and is defined as market capitalisation deflated by total assets. 
Table 7 Probability of being involved in a PTP based on CEO shareholdings, other variables being calculated at their mean values

\begin{tabular}{cc}
\hline CEO shareholding (\%) & Probability of PTP (\%) \\
\hline 10 & 2.11 \\
20 & 3.53 \\
25 & 4.54 \\
30 & 5.83 \\
35 & 7.46 \\
40 & 9.46 \\
50 & 15.07 \\
60 & 23.10 \\
70 & 33.70 \\
\hline
\end{tabular}


Table 8 Logistic regression results of the board, ownership and growth opportunity characteristics of public to private firms and firms remaining public with shareholding and board structure interaction terms

\begin{tabular}{lllll} 
& Model 7 & Model 8 & Model 9 & Model 10 \\
\hline Q & -0.4921 & -0.5140 & -0.4922 & -0.5260 \\
PNX & $(2.12)^{\star \star}$ & $(2.02)^{\star \star}$ & $(2.12)^{\star \star}$ & $(2.05)^{\star \star}$ \\
& 0.0015 & -0.0038 & & \\
PINDNX & $(0.14)$ & $(0.35)$ & & \\
& & & 0.0012 & -0.0065 \\
CEOsh & 0.0345 & & $(0.13)$ & $(0.72)$ \\
& $(2.67)^{\star \star \star}$ & & 0.0345 & \\
INSTITsh & & 0.0227 & $(2.68)^{\star \star \star}$ & \\
& & $(2.70)^{\star \star \star}$ & & 0.0233 \\
CEOsh*Duality & & 0.0977 & & $(2.75)^{\star \star \star}$ \\
& & $(2.91)^{\star \star \star}$ & & 0.0971 \\
INSTITsh*Duality & 0.0104 & & 0.0104 & $(2.93)^{\star \star \star}$ \\
& $(0.98)$ & & $(0.98)$ & \\
FCF & -0.0147 & -0.0112 & -0.0148 & -0.0113 \\
& $(0.81)$ & $(0.63)$ & $(0.81)$ & $(0.63)$ \\
THREAT2 & 0.3405 & 0.4689 & 0.3324 & 0.5129 \\
& $(0.35)$ & $(0.50)$ & $(0.34)$ & $(0.54)$ \\
Constant & 0.0801 & -0.2310 & 0.1001 & -0.1669 \\
& $(0.13)$ & $(0.37)$ & $(0.20)$ & $(0.33)$ \\
$\chi^{2}$ & $14.86^{\star \star}$ & $24.47^{* \star \star}$ & $14.86^{\star \star}$ & $24.86^{\star \star \star}$ \\
\hline
\end{tabular}

$\mathrm{t}$ values in parentheses

*** - significant at 1\%; ** - significant at $5 \%$; * - significant at $10 \%$

$\chi^{2}$ tests the null hypothesis that all the coefficients are zero.

PNX is the percentage of non-executive directors on the board. PINDNX is the percentage of independent directors on the board. Directors are classified as independent if they are nonexecutive directors who have not previously been previously employed either as an executive director of the company or had been employed as an advisor to the company. DUALITY is a binary variable that takes the value 1 if the same person holds the posts of CEO and chairman, and zero if the posts are held by different people. CEOsh is the percentage of ordinary shares held by the CEO, or where appropriate, the executive chairman. INSTITsh is the total percentage shareholdings of institutions, where the shareholding is in excess of 3\%. FCF is a measure of free cash flow. It is defined as operating cash flow minus interest, tax and dividends deflated by sales and converted to a percentage. THREAT2 is a binary variable that takes the value 1 if a company had been the subject of hostile take-over speculation in the financial press and zero if it had not. $\mathrm{Q}$ is the $\mathrm{Q}$ ratio and is defined as market capitalisation deflated by total assets. 